\section{AB0397 ABATACEPT SHOWS BETTER SUSTAINABILITY THAN TNF INHIBITORS WHEN USED FOLLOWING INITIAL BIOLOGIC DMARD FAILURE IN THE TREATMENT OF RHEUMATOID ARTHRITIS: 8 YEARS OF REAL-WORLD OBSERVATIONS FROM THE RHUMADATA ${ }^{\circledR}$ CLINICAL DATABASE AND REGISTRY}

D. Choquette $^{1}$, L. Bessette ${ }^{2}$, E. Alemao ${ }^{3}$, B. Haraoui ${ }^{1}$, F. Massicotte ${ }^{1}$, M. Mtibaa ${ }^{4}$, E. Muratti ${ }^{4}$, J.-P. Pelletier ${ }^{1}$, R. Postema ${ }^{5}$, J.-P. Raynauld ${ }^{1}$, M.-A. Rémillard ${ }^{1}$, D. Sauvageau ${ }^{1}$, A. Turcotte ${ }^{2}$, É. Villeneuve ${ }^{1}$, L. Coupal ${ }^{1}$ ${ }^{1}$ Rheumatology, Institut de recherche en rhumatologie de Montréal (IRRM), Montréal; ${ }^{2}$ Rheumatology, Centre d'ostéoporose et de rhumatologie de Québec (CORQ), Québec, Canada; ${ }^{3}$ Bristol-Myers Squibb, Princeton, United States ${ }^{4}$ Bristol-Myers Squibb, Montréal, Canada; ${ }^{5}$ Bristol-Myers Squibb, Uxbridge, United Kingdom

Background: In the absence of biomarkers predicting response to a specific therapy, the choice of second biologic is based mostly on habit and availability of an alternative agent. Traditionally, a second anti-TNF was the preferred option, but recent registry data point to better responses and retention if a drug with a different mode of action is prescribed.

Objectives: Assess the long-term retention of abatacept (ABA) and TNFi following first biologic (b)DMARD inadequate response in RHUMADATA ${ }^{\circledR}$ registry patients (pts) with RA.

Methods: Data from RHUMADATA ${ }^{\circledR}$ pts with RA prescribed either ABA or TNFi as the second bDMARD after 1 January 2006 were analysed. Pts were followed until treatment discontinuation or 9 January 2017 cut-off. Pt characteristics were compared using descriptive statistics, bDMARD discontinuation rates using Kaplan-Meier methods, and proportional hazard models were used to identify predictors of treatment discontinuation.

Results: Data for 92 and 194 pts prescribed ABA or a TNFi, respectively, as second-line treatment were extracted. No clinically significant differences in baseline characteristics were noted between treatment groups. Most pts were women $(76.2 \%)$, average age (SD) was 45.1 (13.3) years at diagnosis and disease duration 10.8 (9.0) years. Most pts were stopping an anti-TNF agent: $97 \%$ of those who were switched to ABA and $83 \%$ of those who were prescribed a second anti-TNF. Overall, $77.6 \%$ of pts stopped their first bDMARD after $>6$ months of treatment (secondary failure). Significant differences in retention between ABA and TNFi groups (log-rank $p=0.0002$ ) were observed (Table, Figure). Results remained unchanged for pts treated with TNFi only in first line, and primary/secondary failure of the first bDMARD did not affect sustainability

Table 1. First bDMARD failure and retention characteristics of the second bDMARD

\begin{tabular}{|c|c|c|c|c|c|c|}
\hline \multirow{4}{*}{ First bDMARD Failed } & \multicolumn{6}{|c|}{ Second bDMARD } \\
\hline & \multicolumn{3}{|c|}{ TNFi } & \multicolumn{3}{|c|}{ Abatacept } \\
\hline & \multicolumn{2}{|c|}{ Failure type } & \multirow[t]{2}{*}{ All } & \multicolumn{2}{|c|}{ Failure type } & \multirow[t]{2}{*}{ All } \\
\hline & Primary & Secondary & & Primary & Secondary & \\
\hline TNF inhibitor, $n, \%$ & $41,25.5 \%$ & $120,74.5 \%$ & $161,100 \%$ & $17,19.1 \%$ & $72,80.9 \%$ & $89,100 \%$ \\
\hline Other mode of action & $6,18.2 \%$ & $27,81.8 \%$ & $33,100 \%$ & $0,0 \%$ & $3,100 \%$ & $3,100 \%$ \\
\hline & $47,24.2 \%$ & $147,75.8 \%$ & $194,100 \%$ & $17,18.5 \%$ & $75,81.5 \%$ & $92,100 \%$ \\
\hline \multicolumn{7}{|c|}{ Second bDMARD Retention Probability at ${ }^{1}$ : } \\
\hline 6 Months & \multicolumn{3}{|c|}{$64.68 \%(3.45 \%)$} & \multicolumn{3}{|c|}{$83.51 \%(3.89 \%)$} \\
\hline 12 Months & \multicolumn{3}{|c|}{$50.54 \%(3.61 \%)$} & \multicolumn{3}{|c|}{$76.73 \%(4.45 \%)$} \\
\hline 24 Months & \multicolumn{3}{|c|}{$39.77 \%(3.59 \%)$} & \multicolumn{3}{|c|}{$59.97 \%(5.29 \%)$} \\
\hline 60 Months & \multirow{2}{*}{\multicolumn{3}{|c|}{$22.26 \%(3.53 \%)$}} & \multicolumn{3}{|c|}{$36.95 \%(6.17 \%)$} \\
\hline 96 Months & & & & & $0.66 \%(6.61 \%$ & \\
\hline \multicolumn{7}{|c|}{ Biologic Retention Time (years) } \\
\hline \multicolumn{2}{|c|}{ Mean, mean (SE) } & \multicolumn{2}{|l|}{$2.71(0.25)$} & \multicolumn{3}{|c|}{$3.33(0.26)$} \\
\hline \multirow{2}{*}{\multicolumn{2}{|c|}{ Lower Quartile $(95 \% \mathrm{Cl})$}} & \multicolumn{2}{|c|}{$0.36(0.28-0.44)$} & \multicolumn{3}{|c|}{$1.02(0.49-1.29)$} \\
\hline & & \multirow{2}{*}{\multicolumn{2}{|c|}{$\begin{array}{l}1.08(0.71-1.60) \\
4.26(3.25-6.64)\end{array}$}} & \multirow{2}{*}{\multicolumn{3}{|c|}{$\begin{array}{l}3.17(1.92-4.78) \\
++(522-++)\end{array}$}} \\
\hline \multicolumn{2}{|c|}{ Upper Quartile $(95 \% \mathrm{Cl})$} & & & & & \\
\hline
\end{tabular}

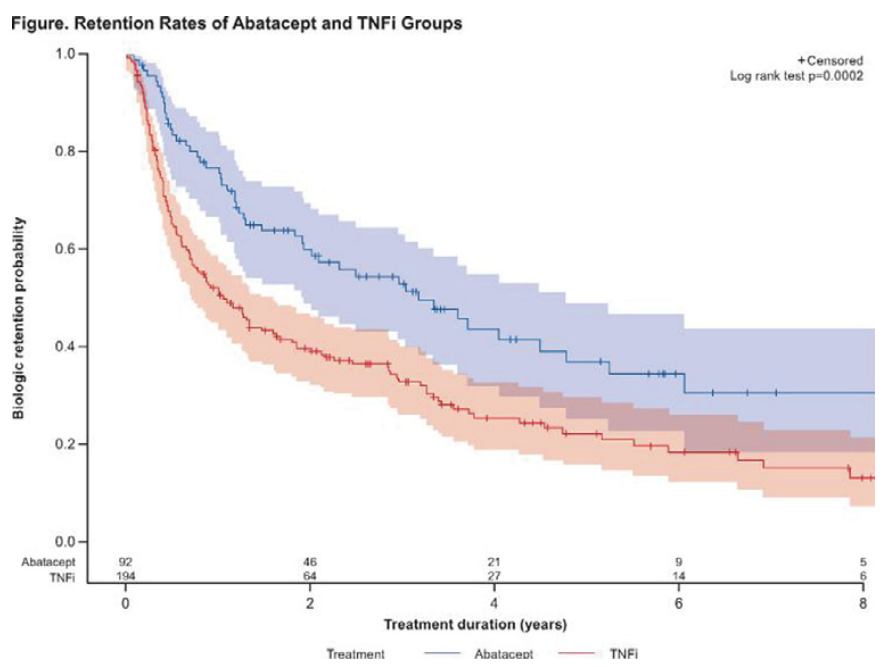

of the second agent. Lack of efficacy $(57.7 \%)$ and AEs (16.5\%) were the most commonly cited reasons for treatment discontinuation.

Conclusions: Abatacept has better sustainability over a second line TNFi in RA patients having failed one prior bDMARD.

Disclosure of Interest: D. Choquette Consultant for: BMS, Speakers bureau: BMS, L. Bessette Grant/research support from: Amgen, BMS, Janssen, Roche, UCB, AbbVie, Pfizer, Merck, Celgene, Sanofi, Lilly, Novartis, Consultant for: Amgen, BMS, Janssen, Roche, UCB, AbbVie, Pfizer, Celgene, Lilly, Novartis, E. Alemao Shareholder of: BMS, Employee of: BMS, B. Haraoui Grant/research support from: BMS, Janssen, Roche, Consultant for: Abbvie, Amgen, BMS, Celgene, Janssen, Merck, Pfizer, Roche, Sandoz, UCB, Speakers bureau: Pfizer, UCB, F. Massicotte: None declared, M. Mtibaa Shareholder of: BMS, Employee of: BMS, E. Muratti Employee of: BMS, J.-P. Pelletier: None declared, R. Postema Shareholder of: BMS, Employee of: BMS, J.-P. Raynauld Speakers bureau: AbbVie, Amgen, BMS, Janssen, Pfizer, Roche, Sanofi, Novartis, UCB, M.-A. Rémillard: None declared, D. Sauvageau: None declared, A. Turcotte Consultant for: Amgen, Abbvie, BMS, Celegene, Janssen, Roche, Pfizer, Lilly, Novartis, Merck, Sanofi, UCB, Speakers bureau: Amgen, Abbvie, BMS, Celegene, Janssen, Roche, Pfizer, Lilly, Novartis, Merck, É. Villeneuve Speakers bureau: Abbvie, Roche, BMS Consultant - Celgene, Cimzia, Pfizer, L. Coupal: None declared

DOI: 10.1136/annrheumdis-2017-eular.2379

\section{AB0398 IMPACT OF BODY COMPOSITION ON RESPONSE TO BIOTHERAPY IN RHEUMATOID ARTHRITIS}

S. Bouden, D. Kaffel, W. Hamdi ${ }^{1,1}$, M.M. Kchir. Rheumatology, Institut kassab, tunis, Tunisia

Background: Biological therapies had greatly improved the treatment of rheumatoid arthritis (RA). The response to biologics may be influenced by many factors. Little is known about the impact of body composition inRA biologics.

Objectives: We aimed to investigate the impact of obesity $(\mathrm{BMI} \geq 30)$ andbody composition (lean mass/ fat mass)on response to biotherapy in RA.

Methods: A retrospective study was performed over a period of 11 years (2006-2016). Patients diagnosed RA (according to the ACR 1987 criteria) and treated by biologics were enrolled. Body composition (lean mass/ fat mass) was measured by X-ray biphotonic absorption (DXA). The threshold of signification was set for a value of $p<0.05$

Results: Fifty patients were enrolled, including 5 men and 45 women (sex ratio $=0.11$ ). The mean age was 66 years [38-79]. The mean duration of RA was 5 years [1-30]. The mean duration of treatment with biologics was 38 months [6-120]. Thirty nine patients were treated by TNF alpha inhibitors $(25$ etanercept, 7 adalimumab, 6 infliximab and 1 certolizumabpegol), 6 rituximab and 5 tocilizumab. Nine patients had a normal weight $(18 \%), 17$ had overweight $(34 \%)$ and 24 had obesity $(49 \%)$. The average percentage of fat mass was 44.8 [23-54], with a median of 46. While comparing obese patients with others, we did not notice a significant difference in the mean variation of the DAS28 at 6 months for TNF alpha inhibitors nor for all biotherapies combined (respectively $p=0.6$ and $\mathrm{p}=0.9$ ). The same result was observed while comparing the DAS28 according to the body composition (relative to the median of the percentage of the fat mass: for TNF alpha inhibitors $(p=0,6)$ and for all biotherapies combined $(p=0,09)$ ).

Conclusions: In our study, there was no change in response to biologics in patients with RA. Further prospective studies with a larger size will be required to confirm or reverse these results.

References:

[1] Iannone F, Lopalco $G$ and al. Impact of obesity on the clinical outcome of rheumatologic patients in biotherapy. Autoimmun Rev. 2016 May;15(5):447-50. doi: 10.1016.

[2] Gardette A, Ottaviani S. Body mass index and response to tocilizumab in rheumatoid arthritis: a real life study. Clin Rheumatol. 2016 Apr;35(4):857-61. doi: 10.1007.

Disclosure of Interest: None declared

DOI: 10.1136/annrheumdis-2017-eular.6107

\section{AB0399 RITUXIMAB TREATMENT AND IMMUNOGLOBULIN LEVELS MONITORING}

G. Kasavkar, S. Kamath. Rheumatology, Haywood hospital, Stoke on Trent, United Kingdom

Background: Rheumatoid arthritis is a well-known inflammatory condition with a prevalence around $1 \%$ in females and $0.5 \%$ in males in UK (as per NOAR study). In the past decade use of biologic therapy has helped clinicians to treat rheumatoid arthritis more effectively. Rituximab is one of the biologics which is used commonly for treating rheumatoid arthritis. Rituximab is chimeric monoclonal antibody targeting CD20 molecule of B cells. First trial of rituximab in treating rheumatoid arthritis was published in 2004 and since then it has shown promising results in trials. In order to guide clinicians British society of rheumatology proposed recommendations in March 2010. An audit is required to ensure adherence to clinical guidelines at Haywood hospital.

Objectives: To assess whether patients receiving Rituximab are appropriately monitored with pretherapy evaluation of immunoglobulin levels 